\title{
Inner-City Suburbanization - no Contradiction in Terms. Middle-Class Family Enclaves are Spreading in the Cities
}

\author{
Susanne Frank ${ }^{1}$ iD
}

Received: 29 March 2016 / Accepted: 30 September 2016 / Published online: 19 October 2016 (C) The Author(s) 2016. This article is available at SpringerLink with Open Access.

\begin{abstract}
The rapid emergence and spread of new housing quarters that specifically address middle-class families is a striking feature of current urban development. Despite being located in or near the city centres, many of these 'family enclaves' display social and physical characteristics that so far have been firmly associated with suburban living. Against this background, the purpose of this article is twofold. The first objective is to argue from a theoretical perspective that the notion of 'inner-city suburbanization' is appropriate and helpful to capture the hybrid and contradictory nature of these projects as well as of many of the current socio-spatial developments in Western metropolitan regions. For this purpose, the paper draws on newer approaches that conceive of (urban or suburban) ways of living as independent of specific (urban or suburban) spaces or places. The second issue, based on empirical research, is then to sketch the essential qualities of newly built middleclass family enclaves and to highlight their propagation as a major characteristic of urban transformation in Germany. Their continuing expansion is interpreted as an expression and catalyst of ongoing processes of inner-city suburbanization. It is asserted that suburbanism has not only made its mark on the outskirts of the cities but is increasingly conquering growing parts of the inner cities as well.
\end{abstract}

Prof. Dr. Susanne Frank

susanne.frank@tu-dortmund.de

1 Fakultät Raumplanung, Stadt- und Regionalsoziologie, Technische Universität Dortmund, August-Schmidt-Straße 10, 44227 Dortmund, Germany
Keywords (Sub)urbanism as a way of living · Inner-city suburbanization · Middle-class family enclaves · New housing developments - Urban transformation in Germany

\section{Innere Suburbanisierung - kein Widerspruch in sich. Über die Verbreitung von Mittelschicht- Familienenklaven in den Städten}

Zusammenfassung Die rasche Entstehung und Verbreitung von neuen Wohnquartieren, welche sich speziell an Mittelschichtfamilien richten, ist ein auffälliges Merkmal aktueller städtischer Entwicklung. Obwohl sie sich in oder nahe den Stadtzentren befinden, weisen viele dieser abgeschirmten Familienenklaven soziale und physische Eigenschaften auf, die bisher fest mit suburbanem Wohnen in Verbindung gebracht wurden. Vor diesem Hintergrund verfolgt der Beitrag zwei Anliegen: Im theoretisch-konzeptionellen Teil soll gezeigt werden, dass der Begriff ,innerstädtische Suburbanisierung“ angemessen und hilfreich ist, um den hybriden und widersprüchlichen Charakter dieser wie auch vieler anderer aktueller sozialräumlichen Entwicklungen in westlichen Metropolregionen zu erfassen. Hierzu stützt sich der Beitrag auf neuere Ansätze, die die (urbanen oder suburbanen) Arten des Wohnens als unabhängig von bestimmten (urbanen oder suburbanen) Räumen und Orten betrachten. Im zweiten, auf empirischer Forschung basierenden Teil werden die grundlegenden Eigenschaften der neuen Familieninseln beschrieben. Ihre Vermehrung wird als Ausdruck und Katalysator der fortschreitenden Suburbanisierung der inneren Städte und damit als wesentliches Kennzeichen urbaner Transformation in Deutschland interpretiert. Gezeigt werden soll, dass Suburbanisierungsprozesse nicht nur die 
Umlandentwicklung prägen, sondern zunehmend auch innerstädtische Gebiete kennzeichnen.

Schlüsselwörter (Sub)urbane Lebensweise · Innere Suburbanisierung · Familienenklaven · Neuere Wohnund Siedlungsentwicklung · Urbane Transformation in Deutschland

\section{Introduction}

In most Western industrialized countries, the development trajectories of urban agglomerations and their interpretations are the subject of intensive and controversial discussion. Although reurbanization is certainly the trend of the time, suburban areas continue to attract residents, jobs, and formerly 'urban' functions in many metropolitan regions. It is not only the contradictory simultaneity of these processes that is puzzling, but also the fact that the clear distinctions between what we used to consider 'urban' and 'suburban' are noticeably fading away. However, while the urbanization of the suburbs has been intensely debated for decades (Fishman 1987; Gober 1989; Garreau 1991), the fact that key features of suburbia and suburban life can now be found in many cities has received much less scholarly attention, especially in Europe and particularly in Germany. One major reason for this blind spot arguably is the widespread understanding of suburbanization as a process that, per definition, takes place outside the cities, namely in their surroundings. From such a 'governmental' or 'container' perspective, the notion of 'inner-city suburbanization' is, of course, a contradiction in terms.

This conceptualization may be crucial in explaining why a significant feature of present urban transformations has evolved without receiving much scholarly attention: the rapid proliferation of newly built middle-class family enclaves in numerous cities, which can be observed in many Western countries. It is striking that many of these residential areas are heavily (sometimes disturbingly) reminiscent of traditional suburbia in form and design, functions and qualities.

Against this background, the purpose of this article is twofold. The first objective is to explain from a qualitative and relational theoretical viewpoint why the notion of 'inner-city suburbanization' is particularly appropriate and helpful to capture the hybrid and contradictory nature of many of the current socio-spatial developments. To this end, I refer to newer approaches that conceive of (urban or suburban) ways of living as independent of specific (urban or suburban) spaces or places. In particular, I benefit from the Canadian geographer Alan Walks' (2013) seminal theorization of suburbanism as a way of life. Drawing on Henri Lefebvre's (1974) dialectical conceptualization of urban- ism, Walks defines suburbanisms along several intersecting and conflicting dimensions that can be found in both urban and suburban locales.

The second issue is then to sketch the essential qualities of newly built middle-class family enclaves and to highlight their propagation as a major characteristic of current urban development. Their continuing expansion will be interpreted as an expression and catalyst of ongoing processes of inner-city suburbanization. When speaking of suburbanization, I refer to "the process of spreading of suburban ways of living to new geographic areas" (Moos/Mendez 2015: 1865). It is thus asserted that in Germany, as in many other Western urban regions, suburbanism has not only made its mark on the outskirts of the cities but is increasingly conquering growing parts of the inner cities as well.

My considerations are based on the theoretical and empirical analysis of the structural and social features of a recently emerging form of family living in several German cities, particularly Berlin and Dortmund. In the course of this explorative project, I have, partly in collaboration with colleagues and Master's students, collected a large variety of visual and auditory data over several years through onsite visits, observations, document analyses, image interpretations, standardized surveys and formal interviews. In addition, I draw on countless informal talks with other parents in my daily life at home and at work. ${ }^{1}$

\section{What is a Suburb?}

Interpreting the spread of inner-city family enclaves as a process of inner-city suburbanization might come as a provocation to many. Planners, in particular, often tend to perceive suburban estates as 'specific places' and 'separate entities' that are by definition located beyond city limits. This view is shaped by adopting a primarily administrative, statistical, and quantitative perspective. Take, for instance, the often cited "stages of urban development model" (van

\footnotetext{
1 The fact that I, as a mother of two children, have first-hand experience with what I investigate has helped me a lot to find access to other parents. I constantly meet other mothers and fathers in the kindergarten, on the school yard, at parents' evenings, in the sports clubs, in the neighbourhood, and in the corridors, offices and canteens of my university. Conversations often arise along the way. My experience is that housing choices and how we locate ourselves with regard to the city's socio-spatial fabric are topics that most parents easily and frankly talk about. Increasingly such discussions also come up at professional meetings or conferences. When I report on my research, colleagues or auditors often contribute their own experiences and considerations. As a consequence, an important amount of my empirical data originates from my personal circles and from informal sources. I have strived to balance this bias by the formal and distanced methods described above. For a detailed description of my approach, see Frank (2017).
} 
den Berg/Drewett/Klaassen et al. 1982), which assumes that it is difficult but possible to draw clear lines between core city, surrounding suburban areas, and more distant regions outside the agglomeration. Such definitions then provide the grounds for clearly distinguishing processes of sub-, counter-, and reurbanization in metropolitan areas. If suburbs are defined by their geographical location outside of an urban core, talking about 'inner-city suburbanism' of course does not make any sense.

What precisely constitutes and characterizes a suburb has been widely debated in academic literature for a long time In a comprehensive overview, Forsyth (2012) examines the vast range of suburban definitions. She distinguishes several "dimensions" according to which "the suburban" has often been classified (Forsyth 2012: $270 \mathrm{ff}$.); among them are built form (e.g. low density, single and semi-detached houses), transportation (e.g. within commuting distance to the core city, street car or automobile-based), activities (e. g. mostly residential or mixed use), sociocultural features (e.g. homeownership, social and ethnic composition, middle-class dominance, family orientation), or period of construction (e.g. post-World War II). Given the huge variety of suburbs today, none of these efforts to nail down an exact definition of a suburb yields convincing results. With regard to the confusing picture she paints, Forsyth claims that we must either abandon the term or use it with greater precision (Forsyth 2012: 278 f.). Similarly, other researchers "consider the term 'suburb' to be obsolete or simply inadequate due to its inability to capture the diversity of neighborhoods contained within suburbs" (Moos/ Mendez 2015: 1868; cf. also Murphy 2007; Florida 2014).

\section{From Place-Based Definitions of Suburbs to Suburbanisms as Ways of Living}

It might therefore be reasonable to abandon the futile attempt to determine what characterizes the suburb as a particular type of physical or social place or space and take a different path instead. In this vein, new approaches that suggest looking at suburban ways of living, or suburbanisms, have been gaining influence in recent years (Keil 2013; Mace 2013; Walks 2013; Moos/Mendez 2015; for older conceptualizations, see Fava 1956; Gans 1968). The plural ('suburbanisms') indicates from the outset that suburban ways of living are as diverse as suburban environments. These approaches are mostly based on a qualitative understanding of how people construct, use, and experience place in their daily lives, and how they invest it with meaning.

It is no coincidence that many of these recent considerations draw on Henri Lefebvre's work on urbanism and everyday life (Lefebvre 1970 [2003]; Lefebvre 1974). According to Lefebvre, the capitalist forces that have evolved in and shaped our cities have long spilled over to 'other' spaces. In his terminology, the urban - which he carefully distinguishes from the city - is a set of social relations that range across and impose themselves through physical space and tend to permeate the entire society. As a consequence, "urban society is not just in the 'city', it is in and of all of society" (Ruppert 2003).

In Lefebvre's dialectical approach, "the urban phenomenon is [...] produced through the tensions between contradictory and simultaneous primary tendencies" (Walks 2013: 1474). In this thinking, the dominant process of centralization as well as the related tendencies towards difference, chance encounters with strangers, complexity, and heterogeneity are permanently ruptured or subverted by their own countering forces: centrifugal dispersion, fragmentation, separation, and segregation, "compartmentalising rationality" and "universalising homogeneity" (Walks 2013: 1475). These conflicting movements constantly create new urban syntheses.

\section{Suburbanism as a "Subset of Urbanism" (Alan Walks)}

In an inspiring article, Alan Walks has built on this line of reasoning to develop a theory of suburbanism, which he conceptualizes "as an inherent aspect of urbanism that is both distinct yet inseparable from it - urbanism's internal ever-present anti-thesis that, in dialectical fashion, stands in productive tension with it, producing interleaved dimensions of "urbanism-suburbanism"” (Walks 2013: 1472). The above-mentioned 'primary' forces towards urbanism (centrality, difference etc.) are continually undermined by opposing forces (namely dispersion, compartmentalization etc.) that work to "'break' the full expression of contemporary urbanity in a qualitative sense" (Walks 2013: 1477). The latter tendencies can be captured by the term 'sub-urbanism' - understood as a "secondary", "limited" or even "subversive" form of urbanism (in terms of "subverting urbanism's full development”, Walks 2013: 1472). In this perspective, suburbanism, in any case, is a property or an expression of urbanism and not its opposite or a lack thereof. Suburbanism is a product and the negation of urbanism at the same time.

With reference to Lefebvre's dialectic, Walks (2013: 1477) stresses that "the forces of urbanism-suburbanism, and the tensions they produce, are in constant flux". He thus suggests theorizing them as "flows that move in and through particular places and spaces, inhabiting them for distinct yet indeterminate lengths of space and time" (Walks 2013: 1477). This perspective on the forces of urbanismsuburbanism as flows is especially productive because it offers important conceptual advantages. 
Table 1 Six distinct dimensions of urbanism-suburbanism

\begin{tabular}{|c|c|c|}
\hline \multirow[t]{2}{*}{ Dimension } & \multicolumn{2}{|l|}{ Ideal type properties } \\
\hline & Urbanism & Suburbanism \\
\hline Centrality (1) - agglomeration & $\begin{array}{l}\text { Clustering, form, distance decay, concentra- } \\
\text { tion }\end{array}$ & $\begin{array}{l}\text { Formlessness, dispersion, flat, gradients, } \\
\text { fragmentation }\end{array}$ \\
\hline Centrality (2) - power & $\begin{array}{l}\text { Co-ordinated decision-making, political } \\
\text { influence, overt authority, control }\end{array}$ & $\begin{array}{l}\text { Marginalisation, subordination, order-taking, } \\
\text { dependence uncoordinated, latency }\end{array}$ \\
\hline Difference (1) - juxtaposition & $\begin{array}{l}\text { Connectivity, simultaneity, fine-grained, } \\
\text { complexity, mixed use, spontaneity }\end{array}$ & $\begin{array}{l}\text { Compartmentalisation, simplicity, separation, } \\
\text { imposed order }\end{array}$ \\
\hline Difference (2) - social diversity & $\begin{array}{l}\text { Plurality, social connectivity, encounter, co- } \\
\text { existence, strangers }\end{array}$ & Division, segregation, avoidance, isolation \\
\hline Functionality (1) - auto-mobility & Multi-functionality, choice, interdependence & $\begin{array}{l}\text { Autonomy, system singularity, auto-mobile } \\
\text { dependence }\end{array}$ \\
\hline Functionality (2) - domesticity-publicity & $\begin{array}{l}\text { Public sphere, publicism, division of labour, } \\
\text { politics, exteriority }\end{array}$ & $\begin{array}{l}\text { Domestic sphere, privatism, family, neigh- } \\
\text { bouring, interiority }\end{array}$ \\
\hline
\end{tabular}

Source: Walks (2013: 1479)

Firstly, it allows us to think of the forces of urbanismsuburbanism as interacting, conflicting, and/or combining with each other in different ways, hence creating new hybrid forms of (sub)urbanisms marked by quite different qualities. We can thus imagine a vast variety of possible (sub)urbanisms (Walks 2013: 1478, 1483). Secondly, it allows us to conceptually separate the forces and features of urbanism-suburbanism from the places that they produce: cities and suburbs, but also small towns and rural areas within a metropolitan agglomeration (Walks 2013: 1478, 1483). Thirdly, the approach permits us to think of urbanism and suburbanism as ideal types (which are not binary opposites) that are endowed with distinct properties (which are not conceptualized as mutually exclusive but can come into contact and interact with each other).

Walks (2013: 1478 ff.) identifies six distinct morphological and sociological dimensions of urbanism-suburbanism that reflect "how people's ways of living are shaped by

1. the distance from the central city,

2. the symbolic distance from positions of power,

3 . the co-location of different land uses and social, economic, cultural and political activities,

4. the diversity of people and households nearby,

5. the reliance on automobiles, and

6 . the degree to which spaces and activities are public versus domestic".

Table 1, taken directly from Walks' publication, illustrates how he ideal-typically characterizes the two poles of urbanism-suburbanism. ${ }^{2}$

\footnotetext{
${ }^{2}$ Other authors using Walks' scheme as an analytical tool for empirical research add the dominance of home ownership, single-family houses, or low densities to the list of distinctive ideal-typical suburban properties (Moos/Mendez 2015).
}

\section{Creative Leeway for the Interpretation of Settlement Patterns}

The conceptual uncoupling of specific places and the ways of living 'normally' associated with them opens up much needed creative leeway for the description and interpretation of the current transformations of settlement patterns and the formation of new spaces for living and working in today's metropolitan areas. On the basis of the six separate (physical and sociological) dimensions described above, theorized as flows that interact and overlap to varying degrees, we can imagine a multiplicity of urbanisms and suburbanisms (Walks 2013: 1483).

Walks' approach is so helpful because it highlights and delineates the hybrid or in-between character of many spaces or places within the polymorphic, fragmented, and complex landscape of contemporary metropolitan regions. In the course of globalization and the related social and spatial restructurings, the boundaries of what we usually refer to as urban or suburban have been blurring for quite a while. His scheme makes it possible to capture the amalgamated, often contradictory and dynamic, nature of many spaces and places in the wider urban fabric.

It enables us, for example, to describe places as urban or suburban independent of their geographical location. Downtown quarters can thus be very suburban whilst suburban areas (and even villages) can (theoretically) exhibit (certain) urban qualities and functions. Also, a place may be urban in one or several dimension(s) and suburban in (an)other(s), hence urban and suburban at the same time. Furthermore, a place may be very stable in one (or more) dimension(s) while rapidly changing in others (Walks 2013: 1483). If we interpret the space spanning the two poles of urbanism and suburbanism as a continuum, we can also describe places as urban or suburban to different degrees, thus as more or less urban or suburban (Moos/Mendez 2015). It 
would also be interesting to work out and compare how different areas in a metropolitan region might be categorized along such a continuum.

The following sections illustrate the extent to which this reasoning is instrumental in describing and understanding the specific urbanistic character and the cultural and political importance of newly built middle-class family enclaves which are rapidly spreading in many core cities.

\section{Middle-Class Family Enclaves are Propagating in the Cities}

In Germany, as in other countries, the current 'renaissance of the inner cities' as places to live in and work marks a profound turnaround in urban development. Like in many parts of the world, the penchant for city life is especially pronounced in affluent and creative milieus. Both in Canada and the US, higher earners are moving to the inner cities while lower earners are heading for the suburbs, thus changing the intrametropolitan geography of income (Murphy 2007; Ehrenhalt 2012; Moos/Mendez 2015: 1864). This clear trend toward reurbanization has been observed in Europe as well (Brake/Herfert 2012).

Particularly remarkable in this context is the fact that, after decades of suburbanization, young families who could indeed afford their own home in the suburbs are making a deliberate choice to stay in or return to the city. This new passion for city life among middle-class families and the corresponding attempts to develop central urban locations to meet the expectations of this much coveted target group are remarkably changing the face and the social fabric of the inner cities.

Municipalities are feverishly attempting to satisfy the demand for single-family homes in the city. For this purpose, urban politicians, planners, and developers are advised to import family-friendly types of housing that are characteristic of suburban spaces (Sandfuchs 2008: 83). In the light of the present competition between municipalities and their surrounding areas, this advice may well fall short of the mark. The consulting firm empirica, which advises and assists numerous German municipalities in matters of housing policy, actually recommends tailoring not only the individual home but also the entire neighbourhood to the needs of parents and children. This involves developing complete residential areas for families that should offer them "all the advantages of living in a suburban single-family residential area, while also convincing them of the benefits of the urban location" (Porsch 2004: 45).

Urban policy and planning very much heed this recommendation, as do developers. The construction of urban single-family dwellings and neighbourhoods is booming. New family quarters are mushrooming especially on waste- lands close to or on the edges of the inner cities. The developments vary considerably in terms of size, style, furnishings, price, degree of seclusion, and hence the target group. They range from basic to luxurious and, typologically, from the still infrequent gated communities through upscale townhouse developments and more modest estates of terraced houses to joint building ventures (Baugruppenprojekte). A large number of these building ventures clearly target active, mobile, and affluent middle-class families, especially of the bourgeois-liberal and the more leftist greenalternative milieus.

The City of Berlin is a prime example and particular case in point because architects and developers have strategically developed specific 'new' types of inner-city building complexes there: the townhouses. Townhouses are a way of importing "the suburban estate of terraced houses to the city centre" (Niendorf 2011: V13; vgl. Burghardt 2010). This increase in the new construction of owner-occupied family dwellings is, however, not limited to the inner city but can also be observed on the less dense inner fringes where the architectural design often displays rather traditional suburban features (i.e. (semi-)detached homes). Dortmund is a textbook example of this latter variant. Some municipalities have developed additional incentives to support family-oriented construction schemes, such as offering subsidized building lots for families with children (e.g., the Hannover-Kinder-Bauland-Bonus program, Landeshauptstadt Hannover 2014). ${ }^{3}$ One striking feature of the newbuild family islands is that they are usually residential-only areas with no or only very little (family-related) consumption infrastructures. The bigger ones may include a kindergarten and a small supermarket. Some do not even have a bakery. 4

\footnotetext{
3 The overall picture of 'new urban family living' (which I cannot present in detail here) also comprises recent developments in the existing building stock where the urbanite middle classes are mainly attracted to historical residential areas, typically the late nineteenth century quarters (Gründerzeit) with their specific social and structural features. The Berlin district of Prenzlauer Berg is a prime example of a family neighbourhood that emerges when a cohort of mainly young academics collectively reaches the family formation stage and then stays in the neighbourhood - yuppies become yupps (young urban professional parents) and dinks become diwiks (double income with kids, cf. Karsten 2003; Frank 2012).

4 This makes a difference to established neighbourhoods that undergo processes of family gentrification. Karsten (2014) shows how the influx of middle-class families into upgrading neighbourhoods near the city centre entails the creation and increase of family-related consumption spaces, both commercial and public. The almost complete absence of such facilities is one of the reasons for me to conceive of the newbuild developments as secluded residential 'islands' or 'enclaves'.
} 


\section{Inner-City Suburbanization}

The rapid emergence and spread of new family enclaves is thus a striking feature of current urban development. I use the term 'new family enclaves' in reference to newly constructed residential areas whose layout and design clearly distinguish them from their historically evolved surroundings and that are tailored to the interests and needs of middle-class families, which I will briefly outline below. My proposition is that the cities' efforts to boost their appeal to the middle classes mainly by creating new family neighbourhoods that transfer the classic features of suburban living and housing to the inner city is a process of inner-city suburbanization. $^{5}$

The new inner-city family neighbourhoods typically are master-planned ensembles with clear-cut boundaries that set themselves apart from their urban environment both materially and symbolically (cf. Rieniets 2011). The many newly constructed townhouse quarters - the "top sellers in the market" (Rohde 2007) - are particularly characteristic examples of this. They reflect the attempt to meet the demand for the classic family home with a garden in the city, albeit in a less space-consuming manner to accommodate the higher cost of land for construction. Compared to urban multi-story residential buildings, the structural density of townhouse neighbourhoods is rather low, yet still higher than on the outskirts. They are usually designed as owneroccupied residential properties. Investors and building developers seek to make sure that every unit bears the distinct and recognizable features of a single-family home (see e. g. cds Wohnbau 2010), especially if they are, as in the case of townhouses, all built next to each other in a row. This is why, for instance, soundproof party walls, separate entrances, a private parking space, and a private yard - even if it is no more than a tiny strip of green - are of paramount importance (own empirics). 'Privacy' is thus a key term in understanding these new residential projects and also a constantly recurring and emphasized theme in advertising and image brochures. The slogan "Townhouses: An Urban Private Affair" ("Urbane Privatsache"), coined for the Prenzlauer Gärten project in Berlin, is a typical example. In some projects, this also means that the right to use the facilities designed to encourage good neighbourship (such as green and other spaces for common use, parks, playgrounds, and paths) should be reserved for the residents of the estate (own empirics, cf. also Rieniets 2011).

The issue of 'neighbourhood safety' is of crucial importance to parents. On the one hand, it should be possible for their children to roam the neighbourhood on their own. On

\footnotetext{
${ }^{5}$ I have discussed this in detail elsewhere (as pointed out in Frank 2013; Frank 2014) and will therefore only briefly summarize my arguments here.
}

the other hand, they want to shield their children from the potential threats or dangers of urban life emanating from road traffic, crime, or encounters with unwelcome (groups of) people, which is another purpose served by the enclave nature of these residential areas. This enclave character is not only accentuated by their distinctive architectural design but, moreover, large parts of these estates are enclosed by walls, fences, or high hedges. Most often, there is internal traffic calming and thus hardly more than residential traffic (own empirics). Inner-city property also guarantees a safe investment (Rieniets 2011) and has long become more valuable than the suburban home as both a monetary investment and a status symbol.

For many of the residents, the socially, culturally, and demographically relatively homogenous composition of the neighbourhood is a key factor in providing a sense of neighbourhood safety and social control. This homogeneity is, of course, strongly determined by the property price but also by the architectural language. Investors and planners know that in managing everyday life, working parents in particular are heavily reliant on functioning networks for mutual support. A high number of neighbouring families with similar lifestyles and consumption patterns is extremely helpful in this respect, especially with regard to (spontaneous) neighbourly childcare but also when it comes to other forms of assistance. To live among 'their own kind' is very important to these middle-class parents because they are aware that smoothly functioning and reliable networks, and hence the ones most suitable for everyday life, thrive in a socially and culturally homogenous environment with shared values. An interlocutor put it bluntly, "I cannot entrust my children to neighbours who let them drink Coca Cola and watch RTL II!" (own empirics). ${ }^{6}$ Hence the desire to be surrounded by neighbours of similar social milieus, who engage in similar lifestyles and also have children. New developments where the residents all move in at the same time are particularly well suited to achieving this.

Moreover, in residential areas dominated by families with similar backgrounds, lifestyles, resources, values, and aspirations, parents also expect to be able to easily find schools where their children will meet peers of their own social group. Parents are seriously concerned about the socialization of their children and especially about the quality of early childhood, school, and other education. This worry embraces not only the acquisition of formal educational certificates. It is equally important for parents to make sure that their children acquire a specific attitude toward education and work, i.e. an appropriate work ethic (cf. Bude 2011). In Germany's large and increasingly segregated cities, one of the most effective ways to ensure this is to withdraw to the more bourgeois residential areas. It has

\footnotetext{
${ }^{6}$ RTL II is a commercial broadcaster, notorious for trash TV.
} 
been long known and need not be further elaborated here that there is a close connection between education and location among the education-conscious middle classes (Butler/ Robson 2003: 146 ff.; Hamnett 2003: 2422).

\section{Urban Villages}

The endeavour to transfer suburban living to the inner city leads to the emergence and spread of 'urban villages': secluded, introverted family housing estates promise a protected, village-like residential environment and living experience in the midst of the colourful world of urban life an experience in which the surrounding city is omnipresent as a point of reference, a contrast, and a complement to one's own way of life. Advertising brochures and residents alike praise these residential communities as islands of tranquillity, safety, order, and familiarity - a rock in the roaring sea of urban buzz. "Are we still in the city? You bet!" was an advertising slogan for the Eldenaer Höfe residential complex in Berlin (cf. Niendorf 2011). Praising the spatial proximity to the city while emphasizing both social and mental distance is the common theme that underlies all these projects. "Can you live in the city and the countryside at the same time?" the investor Stofanel asks rhetorically. Marthashof in Berlin gives a typical answer to this question: "The urban village is a place with green spaces and nature - an idyllic place where people can feel safe and secure" (Ludwig Stoffel, owner of Stofanel, quoted in Schröder 2008). "You [will] leave the restless hustle and bustle of the surrounding metropolis behind and return to the relaxing and comforting atmosphere of your peaceful home at Marthashof". ${ }^{7}$ Even the developer of the Car Loft project in Berlin-Kreuzberg employs this topos in an advertising video entitled "The coolest garage in Berlin". There it says (in verse): "Live in the middle/of the city but with the feeling/of your own house in the country./with a garden and a garage/right on your floor". 8

In Dortmund, the CityQuartier is extolled along these lines: "All [new residents] share the wish to enjoy modern residential comfort [...] in a central but quiet location. The CityQuartier features calm suburban flair in the midst of Dortmund, the Ruhr metropolis. Here, the kids play in the streets without worries. Like this, life is almost perfect". ${ }^{9}$ This rhetoric of combining the best features of city life and a life in proximity to nature while avoiding the downsides of each is a common theme in the history of suburbaniza-

\footnotetext{
7 http://www.stofanel.com/de/marthashof.html\#/Marthashof/Offering (August 24, 2016).

${ }^{8} \mathrm{http}: / /$ www.youtube.com/watch?v=ENCcAO3jAwA (August 24, 2016).

9 http://www.cityquartier.net/ (August 24, 2016).
}

tion (Frank 2003: 275 ff.; Frank 2008). It is closely associated with other characteristics such as the single-family home, typically self-owned and with a (small) yard, family-centredness, socio-economic and cultural homogeneity, emphasis on privacy and community, as well as seclusion from the city and protection from the dangers and uncertainties of city life (encounters with contingency and the unfamiliar/uncanny). The images evoked in this rhetoric, in my view, are a clear sign that the new family quarters represent the transfer of housing preferences and needs to the inner cities that have hitherto mostly been pursued and accommodated in the suburbs.

\section{New Family Enclaves in the Service Society: Functional Equivalents to the Suburban Housing Estates of the Industrial Society}

The diffusion of middle-class family islands in or near the central cities is a prominent feature of current urban development. Drawing on Walks' model, I interpret the new family projects as an expression and a result of strained social and spatial dynamics that gravitate in different directions along different dimensions. In the dimensions of 'centrality' and 'physical functionality' they tend toward the side of 'urbanism', whereas they strongly lean toward the pole of suburbanism in the dimensions of 'difference' and 'social functionality'. They are tailored to the needs of working middle-class parents, who often find it hard to reconcile family life and work obligations. From their point of view, these residential communities are simply practical: both by virtue of their central location and in terms of the social composition of their inhabitants. The close proximity to the inner city offers the necessary services, short distances, and hence major time savings compared to more distant residential areas, and the prevailing social homogeneity facilitates the formation of trustworthy social networks for mutual support. Furthermore, they are the perfect environment for those who enjoy and appreciate the city and its manifold offerings but who doubt that an imponderable urban environment is the best place to raise children - not only for reasons of physical safety. As evidenced particularly in the sphere of schools and education, the formation of enclaves can also be described as a deliberate effort to guard against the status threats and insecurity that might emanate from socially weaker or marginalized groups. ${ }^{10}$

\footnotetext{
10 As I have argued elsewhere (Frank 2016), the wish to withdraw to secluded middle-class areas should not be readily denounced as an act of abandoning social solidarity with the poor and marginalized. Without denying that there might be a grain of truth in these interpretations, I contend that reality is more complicated than this. My empirical findings suggest that the possibility of forming meso- or micro-
} 
For all these reasons, I have suggested interpreting the new family enclaves of the post-Fordist service society as the functional equivalents of the suburban housing estates of the industrial society (Frank 2012). The return of middle-class families to the city is above all rendered possible because the families - as a united force and with the powerful backing of politicians, planners, and investors - succeed in transferring elementary forms and functions, norms and values of suburban life to the towns. Against this background, I propose to view the spread of family enclaves in the cities as a new, hybrid form of suburbanization adapted to the changed gender relations and new working conditions of the flexible economy.

\section{A large variety of inner-city suburbanisms}

In recent years, we have observed the emergence of manifold hybrid spaces and places within the wider urban fabric, created by and for (post-)modern ways of life in the postFordist era, which call into question our traditional, deeply entrenched models of 'urban' and 'suburban'. Among them, there are many - albeit very different - demand- and supply-driven inner-city developments, in particular those that are created by or target the rather affluent populations. Internationally, several authors have observed that "highincome people" who "return" to cities and urban neighbourhoods "bring much of their suburban lifestyles with them" (Florida 2014). Moos and Mendez (2015) show for Canada that richer people are more likely to own singlefamily homes and rely on cars even when they live in central neighbourhoods. Butler (2007: 777) describes some of the newly built projects of London Docklands as designed to cater for the needs of the "classic 'suburbanizer' - to be near but not in or of the city". Given the disproportionate numbers of persons living alone and couples without children in these developments, he concludes "What we seem to be witnessing in Dockland is a coming to the city of a new kind of suburb but with a very different profile in terms of gender and family structure - suburbia for singles and empty nesters, as it were" (Butler 2007: 777). For similar reasons, the rapid 'condofication' of downtown Toronto - which has an exciting gender dimension to it, as there is particularly strong demand from single women - has been dubbed "vertical suburbanization" with reference to home

scale middle-class islands - that is, the opportunity to avoid too close contact with the lifeworlds of the socially vulnerable and marginalized - is an important prerequisite for the otherwise sensitive and supportive sentiment of middle-class parents toward those affected by the social inequalities and injustices of contemporary urban development. A good number of my interlocutors are, for example, in some way or another professionally or socially involved on behalf of poor and deprived social groups. ownership and social and cultural homogeneity (McGinn 2013, see also Kern 2010). Florida (2014) underlines that, in general, high-income people lead similar lives, regardless of where they are located in the urban fabric: "While their urban neighborhoods might be denser and have more tall buildings, and their suburban communities have larger lots and more single-family homes, people living in both types of communities shop in similar stores, send their kids to similar schools and enjoy similar amenities". In her research on middle-class families living in the city, which has many parallels to my work, Karsten (2007) looks at mothers and fathers in Rotterdam who reject traditional suburbia as a place for family life and wish to raise their children in an urban environment. She also considers their residential location in a newly built family neighbourhood to be a "compromise" between different concerns: "an urban suburban enclave" (Karsten 2007: 96, see also van den Berg 2013). All these examples show that there is a great diversity also of inner-city suburbanisms.

\section{Conclusion}

The proliferation of middle-class family enclaves in or near the central cities in particular and of inner-city suburbanisms in general are part and parcel of the present transformation of settlement structures driven by ongoing processes of socio-spatial change. The compilation of the hitherto scattered instances highlights the extent, dissemination and significance of the international phenomenon. Meanwhile, many parts of the cities (even some downtowns) are developed, used, and perceived more like suburbs (see, for instance, Hammett/Hammett 2007) and vice versa. As a consequence, the established labels of 'urban' and 'suburban' no longer seem to capture the place-specific peculiarities that they once did. I hope to have demonstrated the descriptive and analytical benefits that arise when we free ourselves from the fixation on the traditional place-based definition of a suburb as a singular entity or a set of coordinates on a map. If we focus on urbanism and suburbanism as ways of life that are not bound to a specific location, we are much better prepared to understand the fragmented nature of today's metropolitan regions as a patchwork of spaces whose different parts are the product of the varying tensions and interactions of the forces or flows of urbanism and suburbanism, which are contingent on the respective nature and combination of their different dimensions.

Acknowledgements The author would like to thank the anonymous referees for their helpful comments.

Open Access This article is distributed under the terms of the Creative Commons Attribution 4.0 International License (http:// 
creativecommons.org/licenses/by/4.0/), which permits unrestricted use, distribution, and reproduction in any medium, provided you give appropriate credit to the original author(s) and the source, provide a link to the Creative Commons license, and indicate if changes were made.

\section{References}

Brake, K.; Herfert, G. (eds.) (2012): Reurbanisierung. Materialität und Diskurs in Deutschland. Wiesbaden.

Bude, H. (2011): Bildungspanik. Was unsere Gesellschaft spaltet. München.

Burghardt, R. (2010): Von der IBA zum Townhouse. In: Budde, N.; Burghardt, R.; Nedo, K. (eds.): Townhouses. Nürnberg, 31-46.

Butler, T. (2007): Re-urbanizing London Docklands: Gentrification, Suburbanization or New Urbanism? In: International Journal of Urban and Regional Research 31, 4, 759-781.

Butler, T.; Robson, G. (2003): London Calling - The Middle Classes and the Re-making of Inner London. Oxford.

cds Wohnbau (2010): Mitten in Berlin wohnen - Townhouses "Eldenaer Höfe" - Projekt der cds Wohnbau. https://www.youtube. $\mathrm{com} /$ watch? $\mathrm{v}=\mathrm{udNbNeMZmUw}$ (August 16, 2016).

Ehrenhalt, A. (2012): The Great Inversion and the Future of the American City. New York.

Fava, S.F. (1956): Suburbanism as a Way of Life. In: American Sociological Review 21, 1, 34-37.

Fishman, R. (1987): Bourgeois Utopias. The Rise and Fall of Suburbia. New York

Florida, R. (2014): The Fading Distinction Between City and Suburb. In: The Atlantic City Lab. http://www.citylab.com/politics/2014/ 10/the-fading-distinction-between-city-and-suburb/381096/ (August 16, 2016).

Forsyth, A. (2012): Defining Suburbs. In: Journal of Planning Literature 27, 3, 270-281.

Frank, S. (2003): Stadtplanung im Geschlechterkampf. Stadt und Geschlecht in der Großstadtentwicklung des 19. und 20. Jahrhunderts. Opladen.

Frank, S. (2008): Gender Trouble in Paradise: Suburbia Reconsidered. In: DeSena, J. (ed.): Gender in an Urban World. Bingley, 127-148. = Research in Urban Sociology 9.

Frank, S. (2012): Reurbanisierung als innere Suburbanisierung. In: Hill, A.; Prossek, A. (eds.): Metropolis und Region. Aktuelle Herausforderungen für Stadtforschung und Raumplanung. Detmold, 69-80. $=$ Metropolis und Region 8.

Frank, S. (2013): Innere Suburbanisierung? Mittelschichteltern in den neuen innerstädtischen Familienenklaven. In: Kronauer, M.; Siebel, W. (eds.): Polarisierte Städte. Soziale Ungleichheit als Herausforderung für die Stadtpolitik. Frankfurt am Main, 69-89.

Frank, S. (2014): Mittelschichtfamilien als Adressaten und Motoren der Stadt- und Quartiersentwicklung. In: Informationen zur Raumentwicklung 4, 361-371.

Frank, S. (2017): Middle-class family enclavism and solidarity from a distance. Notes from a field of contradictions. In: Mössner, S.; Freytag, T.; Krüger, R. (eds.): Adventures in Urban Sustainable Development: Theoretical interventions and notes from the field. Cambridge, London (forthcoming).

Gans, H. (1968): The Levittowners. Ways of Life and Politics on a New Suburban Community. New York.

Garreau, J. (1991): Edge City: Life on the New Frontier. New York.

Gober, P. (1989): The Urbanization of the Suburbs. In: Urban Geography $10,4,311-315$.

Hammett, J.; Hammett, K. (2007): Suburbanization of New York: Is the World's Greatest City Becoming Just Another Town? New York.

Hamnett, C. (2003): Gentrification and the Middle-class Remaking of Inner London, 1961-2001. In: Urban Studies 40, 12, 2401-2426.
Karsten, L. (2003): Family Gentrifiers: Challenging the City as a Place Simultaneously to Build a Career and to Raise Children. In: Urban Studies 40, 12, 2573-2584.

Karsten, L. (2007): Housing as a Way of Life: Towards an Understanding of Middle-Class Families' Preference for an Urban Residential Location. In: Housing Studies 22, 1, 83-98.

Karsten, L. (2014): From Yuppies to Yupps: Family Gentrifiers Consuming Spaces and Re-inventing Cities. In: Tijdschrift voor economische en sociale geografie 105, 2, 175-188.

Keil, R. (2013): Welcome to the Suburban Revolution. In: Keil, R. (ed.): Suburban Constellations. Governance, Land, and Infrastructure in the $21^{\text {st }}$ Century. Berlin, $8-16$.

Kern, L. (2010): Gendering reurbanisation: women and new-build gentrification in Toronto. In: Population, Space and Place 16, $5,363-379$.

Landeshauptstadt Hannover (2014): Hannover-Kinder-BaulandBonus. http://www.hannover.de/Leben-in-der-Region-Hannover/ Verwaltungen-Kommunen/Die-Verwaltung-der-LandeshauptstadtHannover/Dezernate-und-Fachbereiche-der-LHH/Wirtschaftsund-Umweltdezernat/Fachbereich-Wirtschaft/Grundst\%C3\%BCcks $\% \mathrm{C} 2 \%$ ADvermarktung/Eigenheimf\%C3\%B6rderung/HannoverKinder-Bauland-Bonus (August 16, 2016).

Lefebvre, H. (1970 [2003]): The Urban Revolution. Minneapolis, MN.

Lefebvre, H. (1974): The Production of Space. Oxford, Cambridge, MA.

Mace, A. (2013): City Suburbs: Placing suburbia in a post-suburban world. Hoboken.

McGinn, D. (2013): How single women - and what they want - are shaping the new housing market. In: The Globe and Mail. http:// www.theglobeandmail.com/life/home-and-garden/real-estate/ how-single-women-and-what-they-want-are-shaping-the-newhousing-market/article7442398/ (August 16, 2016).

Moos, M.; Mendez, P. (2015): Suburban ways of living and the geography of income: How homeownership, single-family dwellings and automobile use define the metropolitan social space. In: Urban Studies 52, 10, 1864-1882.

Murphy, A.K. (2007): The Suburban Ghetto: The Legacy of Herbert Gans on our Understanding of the Transformation of Urban Poverty. In: City and Community 6, 1, 21-37.

Niendorf, J. (2011): Marketingschlager Stadthaus. In: Frankfurter Allgemeine Sonntagszeitung No. 20, May 22, 2011, p. V13.

Porsch, L. (2004): Wohneigentumsbildung in der Stadt. Perspektiven einer nachfrageorientierten Stadtentwicklungspolitik in Zeiten des Stadtumbaus. In: vhw Forum Wohneigentum 1, 40-45.

Rieniets, T. (2011): Urban Villages - Ein Reisebericht auf der Suche nach dem Berliner Townhouse. In: ARCH+ 201/202, 96-99.

Rohde, S. (2007): "Townhouses": Zurück in die Stadt. http:// www.stern.de/wirtschaft/immobilien/immobilien/townhouseszurueck-in-die-stadt-586105.html (August 16, 2016).

Ruppert, E.S. (2003): Book review: Henri Lefebvre. The Urban Revolution. In: Canadian Journal of Sociology Online. http://www. cjsonline.ca/reviews/urbanrev.html (August 16, 2016).

Sandfuchs, K. (2008): Die Motive der Wohnstandortwahl und die Bewohnerstruktur innenstadtnaher Neubaugebiete am Beispiel von Hannover. In: Maretzke, S. (ed.): Städte im demografischen Wandel - Wesentliche Strukturen und Trends des demografischen Wandels in den Städten Deutschlands. Wiesbaden, 83-92.

Schröder, T. (2008): Dorfleben für Großstädter. Berlins Immobilienmarkt kennt ein neues Produkt: Das "urban village" soll das Beste aus Großstadt- und Landleben vereinen. In: Berliner Zeitung, August 8, 2008. http://www.berliner-zeitung. de/berlins-immobilienmarkt-kennt-ein-neues-produkt--das-urban-village--soll-das-beste-aus-grossstadt--und-landlebenvereinen-dorfleben-fuer-grossstaedter-15469484 (September 29, 2016).

van den Berg, M. (2013): City Children and Genderfied Neighbourhoods: The New Generation as Urban Regeneration Strategy. 
In: International Journal of Urban and Regional Research 37, 2, 523-536.

van den Berg, L.; Drewett, R.; Klaassen, L.H.; Rossi, A.; Vijverberg,

C.H.T. (1982): A Study of Growth and Decline. Oxford.
Walks, A. (2013): Suburbanism as a Way of Life, Slight Return. In: Urban Studies 50, 8, 1471-1488. 